it will be to ask them to remember that he proved, what the gieatest men have always proved, that it is possible to conciliate the most magnificent knowledge of mathematics or of any abstract science with all the culture of the time. Galileo was an admirable writer; he was a great musician; he studied Ariosto and Dante with intense love; he amused himself with comedy; he distinguished himself in painting. It is the commonplace of the history of great men-a commonplace better illustrated perhaps by the great names of Italy than by those of any other country-that greatness is scarcely compatible with a narrow concentration of intellect, even to one great family of subjects. Many of her great mathematicians were sculptors, painters, poets, masters of expression. But if the story of Galileo's life should guard you from falling into the Scylla of the eager student who thinks that he must dwarf his nature if he hopes to attain to eminence in a special subject-an error to which the pressure of our times renders him more and more liable - it is equally certain to save him from the Charybdis of the dilettante who forgets to choose that one of the objects attainable within the little compass of a man's life which is most suited to his faculties, and in attaining which he is most likely to succeed, Galileo repressed none of his great powers, and denied himself none of the intellectual delights which few men of his day were so able to enjoy. But the obstinacy with which he followed after mathematical and physical truth, from the day when he first listened, as a truant medical student, at the key-hole of a lecture-room to the professor of mathematics teaching the Grand Duke's pages, to that, nearly sixty years after, when the worn-out shell which had suffered so much was laid in that last darkness of the grave, warns us that greatness is never, and, I may add, success is seldom, won without an unfaltering perseverance in the pursuit of the main object of life. The last wish of the venerable old man, whose heart suffered as much from the cruelty which had cut him off, in a sense, from the outward communion of the faithful, as his intellect did when he was compelled, on his knees, to deny what he had proved to be the true system of the universe, was refused him. The Church below refused him burial in the Santa Croce at Florence, but it could not prevent the eyes that old age and suffering had blinded to the delights of his Italian earth from opening on the splendours of an immortality which no man has better earned.

\section{WHO WAS PRINCE ALUMAYÛ?}

$\mathrm{SOME}$ of our contemporaries, referring to the recent death of King Theodore's son, Prince Alumayû, speak of him as if he were an African of the ordinary Negro type. This is perhaps on the whole a fair gauge of the popular ideas still prevalent regarding the natives of the Dark Continent. Yet, though the standard is not of a high order, it must be confessed that in the present case some little confusion might well be pardoned, considering the many difficulties attaching to the subject of Abyssinian ethnology. Indeed it would be no easy matter even for a sound ethnologist to answer the question off-hand, who was Prince Alumayû ? To do so accurately implies a clear knowledge of a very complicated problem, to the elucidation of which a few lines may be welcomed by the readers of NATURE, in connection with an event of some political importance and presenting a very striking parallel in more than one respect to the death of the late Prince Louis Napoleon in Zululand.

It may at once be stated that, whatever else he may have been, the young "Ethiopian," as he has been called, was in no sense an African Negro, and that matters will be much simplified if the "Negro question" be dismissed altogether from the present discussion. There no doubt is some true Negro blood in the lowlands, especially towards the south-west frontier bordering on Senaar ; but in the Abyssinian highlands proper the Negro element seems never at any time to have been present, and at any rate King Theodore of Amhara was no more of Negro stock than are the Rajputs of Northern India. The types have nothing in common except the outward element of colour, though even here great differences prevail, and many of the Abyssinians, especially the women, are rery fair. In all other respects-physique, language, mental qualities - the divergence is fundamental.

This statement applies not only to the ruling peoples of Tigré, Amhara, and Shoa-the "Habesh" properwho are intruders, but also to the true aborigines whether settled or nomad, and who may, for convenience, be here collectively grouped as Agaui, the 'A $y a u$ of Cosmas (about 520 A.D.). The Habesh belong to the Himyaritic branch of the great Semitic family, and must have found their way into the country from the south-western parts of Arabia many hundred years before the Christian era. The Agaii are a section of the Hamitic family intermediate between the Gallas and Somâli of the south, and the Bisharas or Bejas and Egyptians further north. But Semite and Hamite, both originally no doubt one, are themselves mere varieties of the great "Caucasian" type, of which the Aryans are a collateral branch. It follows therefore that Abyssinia is peopled exclusively by races fundamentally distinct from the African Negro, and remotely allied to the fair European stock. Hence Prince Alumay û's affinities are, not with the black inhabitants of the Dark Continent, but with the light, swarthy, and dark peoples of Europe, South-Western Asia, and Northern India.

It will now be more easy to determine his position in the Abyssinian family itself. Although in this area the fundamental elements, as shown, are two only, Hamite and Semite, the intermingling of these elements, continued during a period of probably not less than four thousand years, and taking place under ever-varying conditions, has resulted in no little confusion, and the perplexity has in this case been further intensified by the elements of speech and religion. Thus, the Amharic people, for instance, are usually classed as "Habesh" proper, because of their language ; for Ambarna, notwithstanding many serious differences, is no doubt fundamentally related to the Tigrâi, the purest representative of the old Ghêz (Himyaritic), extinct since the fourteenth century. But it might not be difficult to show that the bulk of the Amharic ${ }^{1}$ nation are ethnically of Agai stock, though now speaking a modified Ghêz dialect imposed upon them by the conquering Semites from the north. At the same time the dominant race in Amhara is no doubt still more akin to the Semites than to the subject race. Hence the late Prince Alumayû, belonging to the royal blood of Amhara, must, on the whole, be regarded as of Habesh (Himyaritic) stock as well as speech.

Religion has been mentioned as a source of confusion, and an obvious case in point are the mysterious Falashas, who, because professing the Jewish faith, are popularly supposed to be of Hebrew nationality. Fortunately, Mr. Edward Hine has not yet got hold of them, and they have consequently not yet been identified with any of the lost tribes. Nevertheless, their position is sufficiently curious and interesting, though it may now be stated with some confidence that they are neither Jews, Israelites, nor Semites. In speech and physique they are a distinct branch of the Agaü (Hamitic) family, and can no more be converted into descendants of Abraham by the practice of maimed Abrahamitic rites than the adoption of Islám can transform the Chinese Panthays into Koreish Bedouins.

The subjoined scheme of the various races now in possession of the Habesh highlands may help to clear up

The very word Amhara has been identified with the Hamra, the chief Agaü nation in the Takazzé valley and province of Lasta, Tigré. 
the obscurity attaching to the subject of Abyssinian ethno$\log \mathrm{y}:-$

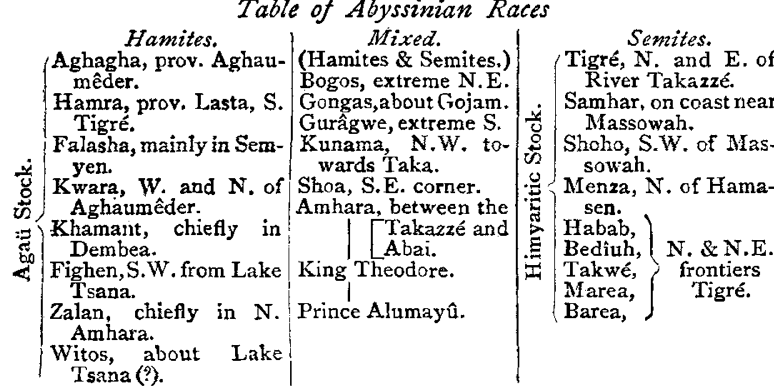

Of the languages three only are of any literary or political interest: Ghêz, still surviving as the language of the liturgy and Sacred writings, though scarcely understood even by the clergy; Tigrái, its purest modern representative, current throughout the kingdom of Tigre and generally north and east of the Takazze; Amharna, spoken with considerable dialectic variety in Amhara and Shoa. All are written in a peculiar syllabic character showing certain affinities to the Himyaritic rock inscriptions of Marah and other parts of South Arabia. Amharic employs seren additional letters for sounds not occurring in Ghêz or Tigrâi, making with the vocal modifications a total of 249 distinct symbols. This was the language of Prince Alumayû.

A. H. KEANE

COLOUR-VISION AND COLOUR-BLINDNESS

$A S$ the notices of these subjects which have recently A appeared in NATURE appear to me to do scant justice to the received theory, will you permit me to call attention to a portion of the evidence on which this theory rests?

The Philosophical Transactions for 1860 contain a paper by Prof. Clerk Maxwell, in which actual measurements are given of the quantitative relations between various colours, some of the observations having been taken by persons of normal vision, and others by a colourblind person. The instrument of observation consisted of a species of spectroscope with three parallel slits, the widths of these slits, and also the distances between them being variable at pleasure. By this means three overlapping spectra are obtained, and any three spectral colours can be mixed in any proportions. The observations showed that any four colours as presented to the eye in a given spectrum are connected with each other by a definite colour-equation, such as-

$$
3 A+4 B=2 C+6 D \text {, }
$$

which means that if the four colours $A, B, C, D$, as they exist in the given spectrum, are increased in intensity threefold, fourfold, twofold, and sixfold respectively, and then mixed two and two, the mixture $3 A+4 B$ will present exactly the same appearance as the mixture $2 C+6 D$. This is only another way of saying that colour as seen by nornal vision contains three independent variables, or requires three numbers for its specification. Any three colours of the spectrum will serve as the three specifying elements; for example, if we employ $A, B$, and $C$ to specify $D$, the specification will be-

$$
D=\frac{1}{2} A+\frac{2}{3} B-\frac{1}{3} C \text {. }
$$

Here we have one coefficient (that of $C$ ) with the negative sign. The three primary colours are defined to be those which will always have positive coefficients when they are employed as the specifying elements. In plainer words, all other colours can be exactly imitated by mixtures of the primaries, whereas, in the above example, the colour $D$ cannot be imitated by a mixture of $A, B$, and $C$.

The points of the spectrum at which the three primary colours are found, will not necessarily be the points which most strongly excite the three elementary colour-sensations respectively. On the contrary, as a matter of fact, the two extreme sensations (called by Maxwell the red and the blue) are very feebly excited at the parts of the spectrum where they are purest, namely, at the extreme ends of the spectrum; and the middle sensation, which is largely adulterated with the other two even at the point where it is purest (namely, at a point in the olive green, which is, accordingly, one of the three primaries), has not a maximum of intensity at this point, but increases in intensity as the brightest part of the spectrum is approached, and attains its maximum (for the solar spectrum obtained with a flint glass prism), somewhere between the fixed lines $E$ and $D$. The determination of the position of the middle primary in the spectrum, was made with considerable precision in the paper referred to ; but the faintness of the two extremities of the spectrum rendered wide slits necessary in examining these regions, and thus introduced inaccuracy in determining the positions of the two extreme primaries, which in later publications Prof. Maxwell places at the very extremities of the spectrum.

The latter part of the paper of 1860 consists of a postscript containing observations made by a colour-blind person. The colour-equations found by direct observation are given, and are shown to agree with the supposition that the observer's vision was dichroic, the sensation corresponding to the extreme red being absent. The curves of intensity for each of the two elements in the vision of the dichroic observer are given, side by side with the three curves of intensity for the vision of a trichroic observer, all these being directly calculated from the observations, and the two dichroic curves appear to be practically identical with two of the three trichroic curves.

Dr. Pole's objection to the received theory appears to me to have no force except in so far as it is an objection to a name. The colour which the colour-blind see in the less refrangible half of the spectrum appears to be due to the excitement of the middle one of the three elementary sensations of trichroic vision. Persons of normal vision never get this sensation without large adulteration, and bence ordinary language contains no appropriate name for it.

Prof. Hering's theory of colours, as expounded by Dr. Pole (NATURE, vol. xx. pp. 479,480 ) seems inconsistent with the fact (established by the observations of Prof. Maxwell, Lord Rayleigh, and other competent observers) that there is one definite colour-equation between any four colours. For Prof. Hering's theory assumes four elements of colour-sensation, $R, G, B, Y$, such that

$$
R+G=0, B+Y=0 \text {. }
$$

It would follow that, with the belp of the minus sign, alf colours could be specified in terms of $R$ and $B$, and hence by writing down the specifications of any three colours, and employing the ordinary processes of elimination, a colourequation could be obtained between the three colours. Prof. Hering's theory then leads to the result that there is a definite colour-equation between any three colours; in other words, that when any three colours are given it is possible to imitate one by a mixture of the other two. This result is so utterly opposed to fact, that a theory which leads to it cannot stand for a moment.

\section{J. D. EvERETT}

\section{SOME OBSERVATIONS ON FLEUSS'S NEW PROCESS OF DIVING AND REMAINING} UNDER WATER

I HAVE recently had two opportunities of seeing a new process of diving and of remaining for a long time under water, called, after its inventor, Fleuss's process. The peculiarity of it is that the diver takes down with him such a good and wholesome supply of air-food, that he is 